\title{
Therapeutic play: preparing the child for the vaccine
}

\author{
Brinquedo terapêutico: preparando a criança para a vacina \\ Jéssica Etienne Dourado Pontes ${ }^{1}$, Elaine Tabet ${ }^{2}$, Maria Áurea dos Santos Folkmann², \\ Mariana Lucas da Rocha Cunha ${ }^{1}$, Fabiane de Amorim Almeida ${ }^{1}$
}

\begin{abstract}
Objective: To identify and compare behaviors of children during vaccination, who were prepared or not for the procedure using an instructional therapeutic play. Methods: A quasi experimental study, with quantitative approach of 60 children aged 3 to 6 years. The child's reactions were recorded in a checklist. Data were analyzed using descriptive and inferential statistics and Fisher's test. Results: The main reactions in the experimental group were stay still $(25 ; 83 \%)$ and spontaneously collaborate $(24 ; 80 \%)$. In the control group, the main reactions were cries and cling to parents (15; 50\%), flushing $(11 ; 36.67 \%)$ and moving the body/agitated (10;33.3\%). Conclusion: The reactions of cooperation were more frequent in the experimental group, while low acceptance was observed only in the control group. Therapeutic play has proved an important tool in preparing for the vaccine.
\end{abstract}

Keywords: Play and playthings; Immunization; Child; Pediatric nursing; Child health; Humanization of assistance; Vaccines

\section{RESUMO}

Objetivo: Identificar e comparar os comportamentos das crianças durante a vacinação, preparadas ou não para 0 procedimento com 0 brinquedo terapêutico instrucional. Métodos: Estudo quasi experimental, de abordagem quantitativa, com 60 crianças entre 3 e 6 anos. As reações da criança foram registradas em um formulário do tipo checklist. 0s dados foram analisados por estatística descritiva e inferencial, e pelo teste de Fisher. Resultados: As principais reações no grupo experimental foram ficar quieta $(25 ; 83 \%)$ e colaborar espontaneamente $(24 ; 80 \%)$. No grupo controle, foram: chorar e agarrase aos pais $(15 ; 50 \%)$, rubor facial $(11 ; 36,67 \%)$ e movimenta-se/agitase $(10 ; 33,3 \%)$. Conclusão: As reações de cooperação foram mais frequentes no grupo experimental, enquanto as de menor aceitação foram observadas apenas no grupo controle. 0 brinquedo terapêutico revelou-se um importante instrumento no preparo para a vacina.

Descritores: Jogos e brinquedos; Imunização; Criança; Enfermagem pediátrica; Saúde da criança; Humanização da assistência; Vacinas

\section{INTRODUCTION}

Playing is one of the most meaningful aspects in a child's life. It is as important as hygiene, feeding, sleeping, and other basic needs..$^{(1-3)}$

Playful activities are essential for the development of children; by playing, children relate with people and the surrounding environment since their early years of life. $^{(1,2)}$

By playing, children learn things that cannot be taught about their world and about themselves: what they can do, how to interact with things and in specific situations, and how to adapt to social demands. ${ }^{(4)}$

Playing is not only essential for the developmental process; it also helps children adapt to new situations, and maintain and recover health. Playing provides pleasure, relaxation, and favors spontaneity. It is extremely significant in crucial times for children, such as during painful procedures. ${ }^{(4)}$

The way children learn and express their suffering is different from that of adults, since they are still incapable of verbalizing feelings. With playful activities, children find a way to reveal their internal world in a symbolic manner. ${ }^{(5)}$

Therefore, it becomes clear that it is crucial for children to play in order to meet their social and psychological needs by providing a restructured experience that helps overcome suffering in moments of tension.

There are several kinds of playing that are classified in different manners. As to its purpose, playing can be classified as follows: (1) recreational, entertaining and distracting the child, who engages for the mere pleasure of playing; (2) stimulating, favoring the development of cognitive, social, creative and sensorimotor skills; (3)

\footnotetext{
Curso de Graduação em Enfermagem, Faculdade Israelita de Ciências da Saúde Albert Einstein, São Paulo, SP, Brazil.

${ }^{2}$ Sociedade Beneficente Israelita Brasileira Albert Einstein, Programa Einstein na Comunidade de Paraisópolis, São Paulo, SP, Brazil.

Corresponding author: Jéssica Etienne Dourado Pontes - Avenida Francisco Morato, 4,293 - Vila Sônia - Zip code: 05521-200 - São Paulo, SP, Brazil - Phone: (55 11) 3746-1070

E-mail: jessica.etyenne@gmail.com

Receveid on: Oct 1, 2013 - Accepted on: Apr 20, 2015

Conflict of interest: none.

DOI: 10.1590/\$1679-45082015A02967
} 
socializing, making the child establish social relations with other children by playing roles in symbolic play, learning his/her sexual role (boy and girl) and what is right and what is wrong; and (4) therapeutic or cathartic, which allows for the diagnosis of difficult situations experienced by the child. Therapeutic play has a curative role as an "escape valve", reducing anxiety and relieving tension. ${ }^{(1,2)}$

Several studies showed that therapeutic play are often used by healthcare professionals, specially nurses. ${ }^{(6-12)}$ This technique is recommended for any child experiencing an atypical conflict situation for his/her age; it can be developed by several professionals anywhere, and is based on play therapy. ${ }^{(1,2)}$

Although therapeutic play and play therapy are terms used inadvertently as synonyms, their concept and applicability differ. ${ }^{(1)}$ Play therapy is a psychiatric technique, and therefore carried out by a skilled professional (psychiatrist, psychologist or psychiatric nurse). It is developed in a controlled environment, and used to treat children with emotional disorders (neurosis or psychosis)..$^{(1,2,13,14)}$

One of the several uses of therapeutic play is to prepare children for therapeutic and painful procedures. This type of playing is called instructional. Here, the child learns about and handles the instruments used in the procedure, expressing his/her fears by acting out the situation that will be experienced. (1,2,15) $^{(1,2)}$

One of the stages of development that benefit most from the use of therapeutic play is the preschool phase, comprising children aged 3 to 5 years, when magical thinking prevails. ${ }^{(5,16)}$

In this stage of life, the cognitive and psychoemotional structure of the child is still under development, and therefore their resources to face painful situations are limited; moreover, they are not able to understand reality, very often relying on fantasy. ${ }^{(1,5)}$

Painful procedures cause fear and physical and emotional suffering to children, mainly when the procedure is not explained to them, and they are not prepared or supported properly. Based on the understanding that the toy is the main means of communication between the child and the professional, the authors of this study proposed to explore the use of therapeutic play to prepare children for vaccination, as well as the influence of this activity on their behavior during the procedure.

\section{OBJECTIVE}

To identify behaviors of children during vaccination after preparation with an instructional therapeutic play; to compare these behaviors in children who were prepared and those who were not prepared.

\section{METHODS}

This is a quasi experimental study of quantitative approach. The analysis of the independent variable (use of toy in preparation for the procedure) and the dependent variable (child's reactions using the toy or not) involved the participation of a control group. However, subjects were not randomly selected, and therefore this is not a true experimental study.

The study was carried out in the pediatric outpatient clinic of the Programa Einstein na Comunidade de Paraisópolis [Einstein Program in Paraisópolis Community], by the Faculdade Israelita de Ciências da Saúde Albert Einstein from November 2009 to November 2010. Data collection and analysis were performed between July and September 2010, after approval by the Research Ethics Committee of Hospital Israelita Albert Einstein, under number 10/1353, CAAE number: 0087,028,000-10 and authorization by the outpatient clinic manager.

Our sample was composed of 60 children aged from 3 to 6 years and 11 months, submitted to vaccination, whose legal guardians agreed to and authorized participating in the study, and signed the Informed Consent Form.

Children were distributed to an experimental group, with 30 children taking part in an instructional therapeutic play session before vaccination, and to a control group, with 30 children who did not receive any kind of previous emotional preparation.

Data were collected by means of observation of the child during vaccination and interview with their legal guardians. Data were recorded in a form with information about identification of child and the reactions during vaccination.

After informing children and their legal guardians about the study and their participation, those selected for the experimental group were invited to play. Instructional therapeutic play sessions were carried out individually, using a doll, disposable syringes, needles, cotton, and bandages for venal puncture. The researcher showed the procedure in the doll and asked the child to participate and repeat the procedure at the end of the role play.

After the instructional therapeutic play session that lasted, on average, 20 minutes, the child and the companion were referred to the vaccination room, where the child was individually observed by the researcher during vaccination. 
Children in the control group and their companions were referred straight to the vaccination room with the researcher, who also observed their reactions during the procedure.

Data were quantitatively analyzed by descriptive and inferential statistical techniques using Fisher's exact test, which assesses the differences between the incidence of children's reactions in experimental and control groups. ${ }^{(17)}$

\section{RESULTS}

The characteristics of the children showed a very close gender-related distribution, with a slight prevalence of boys $(31 ; 51.7 \%)$. In the experimental group, most children were girls $(18 ; 60 \%)$ and in the control group, most were boys (19;63.3\%). The mean age was 4.5 years (standard deviation $-\mathrm{SD}=0.9$ ), ranging from 3 years to 6 years 11 months.

Most children (40;66.7\%) attended school, and all had been vaccinated before; however, they had not received any kind of emotional preparation.

Aggression-related reactions during injection were only observed in the control group, and included mainly pushing $(8 ; 26.7 \%)$ and pulling the hand of the professional $(3 ; 9.9 \%)$. Some children kicked $(2 ; 6.6 \%)$ and hit or bit $(1 ; 3.3 \%)$.

Most children in the experimental group whose reactions involved moving their bodies stayed still during the procedure $(25 ; 83 \%)$, while agitation $(10 ; 33.3 \%)$ and muscle stiffness $(9 ; 30 \%)$ prevailed in the control group (Figure 1).

Figure 2 shows that reactions involving verbal expression were more frequent in the control group; the most prevalent reactions were screaming $(8 ; 26.7 \%)$, saying it would hurt, and refusing the procedure in order to avoid it $(7 ; 23.3 \%)$.

As to emotion-expression reactions, children in the experimental group collaborated spontaneously $(24 ; 80 \%)$ and were at ease $(15 ; 50 \%)$, smiling $(9 ; 30 \%)$ during the procedure. Crying (15;50\%), flushing (11;36.7\%) and perspiration $(7 ; 23.3 \%)$ prevailed in the control group. Compared to the control group, fewer children in the experimental group cried during the procedure $(11 ; 36.7 \%)$ (Figure 3).

Behaviors that showed dependence, such as clinging to their parents $(15 ; 50 \%)$ and asking for cuddling $(6 ; 20 \%)$, were only observed in the control group.

Most reactions related to a greater acceptance of the procedure, such as staying still, smiling, collaborating, and being at ease, were more frequent in the experimental group. Statistical analysis by means of the Fisher's exact test showed that the differences were significant for standing still $(\mathrm{p}=0.006)$ and collaborating spontaneously $(\mathrm{p}=0.015)$, with significance level at $5 \%$.

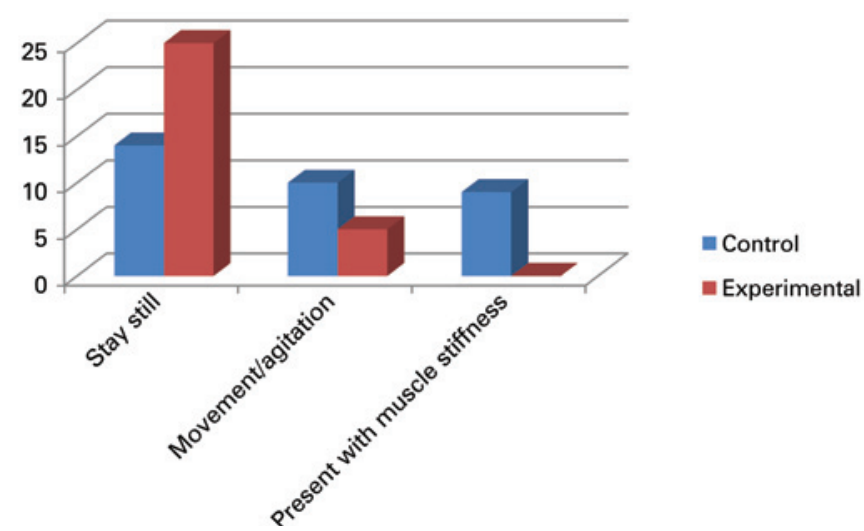

Figure 1. Reactions involving body movement in children of the control and experimental groups

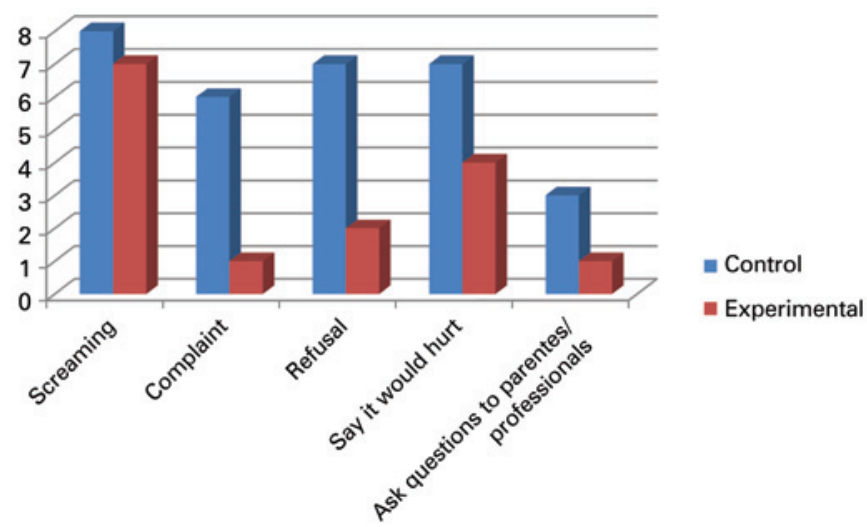

Figure 2. Reactions related to verbal expression in children of the control and experimental groups

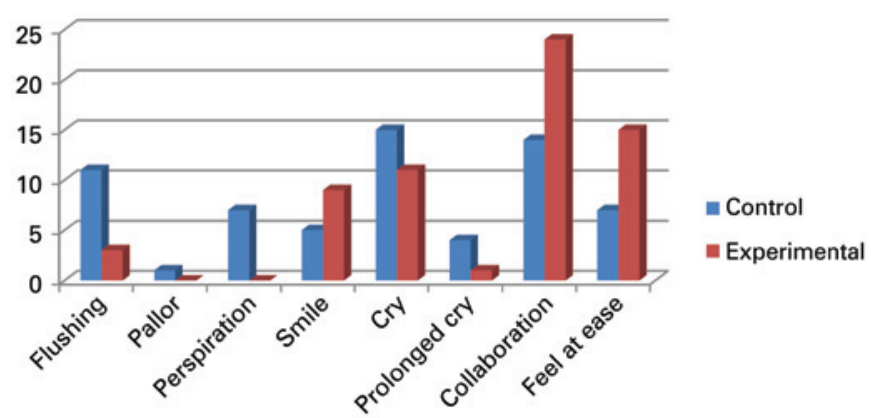

Figure 3. Reactions that show emotional expression in children of the control and experimental groups

Some of the reactions that show less acceptance of the procedure were not observed in the experimental group, such as hitting, kicking, pushing, biting, pulling the hand of the professional, clinging to their parents, 
asking for cuddling and showing muscle stiffness, pallor, and perspiration. Statistical analysis with Fisher's test showed that differences were significant for pushing $(p=0.005)$, clinging to their parents $(p=0.000)$, asking for cuddling ( $\mathrm{p}=0.024)$, and muscle stiffness $(\mathrm{p}=0.002)$.

\section{DISCUSSION}

Reactions indicating aggression (pushing and agitation) were observed more often in the control group when compared to the experimental group, in which children stayed more still and at ease, and collaborated with the procedure. This finding highlights the importance of explaining what will be done to them previously.

In the instructional therapeutic play session, children from the experimental group had the opportunity to deal with the painful experience beforehand, reducing stress and fear. These feelings are very often triggered by magical thinking, typical of the pre-school stage..$^{(4,11,16)}$ Most children from control group $(27 ; 90 \%)$ and experimental group $(24 ; 80 \%)$ were toddlers.

A study on the behavior of children during postoperative dressing showed that after preparation with the instructional therapeutic play, manifestations indicating greater adaptation and acceptance were more frequent, in agreement with our findings. Children observed the professional carefully, verbalized their feelings, showed relaxed posture and facial expressions, played, asked questions to their mothers and to the professional, and assisted with the procedure spontaneously. ${ }^{(17)}$ These behaviors highlight the role of therapeutic play in reducing fear, tension and pain during procedures.

Reactions related to expressing feelings also indicate their state of tension and fear. These reactions were identified more often in the control group and included screaming, crying, saying it would hurt, and also perspiration, pallor, and flushing. ${ }^{(18)}$

Considering the study mentioned previously, ${ }^{(17)}$ behaviors of lower adaptation and acceptance were also more frequent in the control group, in which children were not prepared with the therapeutic play before dressing. Children collaborated passively, stayed quiet, and adopted protective behaviors, facial expressions of fear, and muscle tension, requesting the presence of their mothers.

The more children know about what is going to happen, the less afraid they feel. The toys help them deal with reality, allowing them to experience the painful procedure in a concrete way. ${ }^{(2,10,11,19,20)}$

A study carried out with oncologic children on the use of therapeutic play to relieve pain shows that besides scoring lower in pain assessment after playing, other pain-related characteristics were also less frequent, such as crying, facial expressions, defensive behaviors, and verbal reports. By reducing children's fear and anxiety and improving their mood, the therapeutic play provides pain relief. ${ }^{(21)}$

Another study carried out with toddlers prepared with the therapeutic play before outpatient chemotherapy showed more positive behaviors towards the procedure while playing. Children cooperated with the professional when acting out the procedures, kept a relaxed posture, and smiled. This study highlights the importance of playing to establish a bond of trust between the child and the professional, helping children understand what will happen to them and feel less cautious. ${ }^{(22)}$

Similar data were found in another study also carried out with toddlers recently admitted to hospital and submitted to the therapeutic play. After playing, children were happier, focused on what was happening around them, and responded better to stimuli and requests, indicating higher interaction with professionals and the environment. Besides favoring interactions, playing also helped children accept treatment and perceive admission as less scary. ${ }^{(19)}$

In our study, actions indicating greater emotional control were prevalent in the experimental group as opposed to the control group. The literature shows that after preparation with the toy, children can better control their emotions and collaborate with the procedure. ${ }^{(17,19)}$

Children who were not prepared for an unknown and/or painful procedure are less able to deal with reality, and they rely on fantasy. ${ }^{(6,11)}$ Toddlers cannot express their suffering verbally, and a toy is a genuine way of expressing what they feel and think. ${ }^{(5)}$

When allowed to express themselves freely while playing, children give adults the opportunity to clarify misconceptions that cause fear and apprehension, reducing negative behaviors during procedures. ${ }^{(9,17)}$

However, although the toy allows children to express their emotions freely, one should not expect that they would never cry or scream during the procedure after preparation, as observed in some children from our experimental group. Children trust the person who plays with them; they feel understood and at ease to react freely, without being afraid of professionals telling them off. ${ }^{(3)}$

\section{CONCLUSION}

Children prepared with the instructional therapeutic play before vaccination had reactions that indicated 
higher acceptance during the procedure. They stayed still, collaborated spontaneously, showed to be at ease, and smiled.

Reactions related to lower acceptance of the procedure prevailed among children who were not prepared with the instructional therapeutic play. These reactions included crying, pushing, agitation, muscle tension, flushing, and perspiration.

The therapeutic play was shown to be efficient to prepare children for vaccination, highlighting its value in child care. It is recommended that this practice becomes a routine not only in hospital settings, but also in all different contexts of child care.

\section{REFERENCES}

1. Ribeiro $C A$, Borba Rl, Rezende MA. 0 brinquedo na assistência à saúde da criança. In: Fujimori E, Ohara CV, organizadores. Enfermagem e a saúde da criança na atenção básica. São Paulo: Manole; 2009. p. 287-327.

2. Ribeiro CA, Almeida FA, Borba RI. A criança e o brinquedo no hospital. In: Almeida FA, Sabates AL, coordenadores. Enfermagem pediátrica: a criança, 0 adolescente e sua família no hospital. São Paulo: Manole; 2008. p. 65-77.

3. Almeida FA. Psicologia do desenvolvimento: a criança. In: Farah OG, Sá AC, organizadoras. Psicologia aplicada à enfermagem. Barueri (SP): Manole; 2008. p. 30-59.

4. Sanders J. Cuidado centrado na família da criança durante a doença e hospitalização. In: Hockenberry MJ, Wilson D, Winkelstein ML, editores. Wong Fundamentos de enfermagem pediátrica. 8a ed. Rio de Janeiro: Elsevier; 2011. p. 675-702.

5. Almeida FA. Brinquedo no hospital: preparando a cirurgia para a cirurgia cardíaca. In: Viegas D, coordenador. Brinquedoteca hospitalar: isto é humanização. Rio de Janeiro: Wak; 2007. p. 133-40.

6. Cruz DS, Virgínio NA, Maia FS, Martins DL, Oliveira AM. Therapeutic toy: integrative review. J Nurs UFPE. 2013;7(5):1382-9.

7. Schenkel IC, Garcia JM, Schivinski Cl, Silva ME. Brinquedo terapêutico como coadjuvante ao tratamento fisioterápico de crianças com afecções respiratórias. Psicologia: Teoria e Prática. 2013;15(1):130-44.
8. Almeida FA. 0 brinquedo na pesquisa em enfermagem pediátrica. Rev Soc Bras Enferm Ped. 2014;48(3):423-9.

9. Maia EB, Ribeiro CA, de Borba RI. [Understanding nurses' awareness as to the se of therapeutic play in child care]. Rev Esc Enferm USP. 2011;45(4):839-46. Portuguese.

10. Bento AP, Amorim HC, Aquino Filho MB, Oliveira CS. Brinquedo terapêutico: uma análise da produção literária dos enfermeiros. Rev Eletr Gestão e Saúde. 2011;2(1):208-23.

11. Magnabosco G, Tonelli AL, Souza SN. Abordagens no cuidado de enfermagem à criança hospitalizada submetida a procedimentos: uma revisão de literatura. Cognitare Enferm. 2008;13(1):103-8.

12. Leite TM, Shimo AK. [Use of toys in hospitals: what are Brazilian nurses studying?] Rev Esc Enferm USP. 2008;42(2):389-95. Portuguese.

13. Walker C. Use of art and play therapy in pediatric oncology. J Pediatr Oncol Nurs. 1989;6(4):121-6.

14. Green CS. Understanding children's needs through therapeutic play. Nursing 1974:4(10):31-2.

15. Vessey JA, Mahon MM. Therapeutic play and the hospitalized child. J Pediatr Nurs. 1990;5(5):328-33.

16. Monroe RA. Promoção da saúde do pré-escolar. In: Hockenberry MJ, Wilson D, Winkelstein ML, editores. Wong fundamentos de enfermagem pediátrica. 8a ed. Rio de Janeiro: Elsevier; 2011. p. 449-64.

17. Kiche MT, Almeida FA. Therapeutic toy: strategy for pain management and tension relief during dressing change in children. Acta Paul Enferm. 2009:22(2):125-30.

18. Heldt E, Marini M, Silva ES. Diagnósticos de enfermagem com base em sinais e sintomas na saúde mental. In: Silva $E R$, Lucena $A F$, organizadores. Diagnósticos de enfermagem com base em sinais e sintomas. Porto Alegre: Artmed; 2011. p. 301-19.

19. Campos MC, Rodrigues KC, Pinto MC. The evaluation of the behavior of preschool newly admitted to the pediatric unit and the use of therapeutic play. einstein (São Paulo). 2010;8(1):10-7.

20. Almeida FA, Bomtempo E. 0 brinquedo terapêutico como apoio emocional à cirurgia cardíaca em crianças pequenas. Bol Acad Paul Psicol. 2004;24(1/04):35-40.

21. Sabino MB, Almeida FA. Therapeutic play as a strategy for pain relief in children with cancer. einstein (São Paulo). 2006;4(3):179-86.

22. Artilheiro AP, Almeida FA, Chacon JM. Use of therapeutic play in preparing preschool children for outpacient chemotherapy. Acta Paul Enferm. 2011; 24(5):611-6. 